\title{
Review
}

\section{Coupling endoplasmic reticulum stress to the cell death program}

\author{
RV Rao ${ }^{1}$, HM Ellerby ${ }^{1}$ and DE Bredesen ${ }^{*, 1,2}$ \\ 1 Buck Institute for Age Research, 8001 Redwood Boulevard, Novato, CA \\ 94945, USA \\ 2 University of California, San Francisco, San Francisco, CA, 94143, USA \\ * Corresponding author: DE Bredesen, Buck Institute for Age Research, 8001 \\ Redwood Boulevard, Novato, CA 94945-1400, USA; \\ Tel: + 415-209-2090; Fax: + 415-209-2230; \\ E-mail: dbredesen@buckinstitute.org
}

Received 14.7.03; accepted 30.7.03; published online 6.2.04 Edited by Dr M Piacentini

\begin{abstract}
The endoplasmic reticulum (ER) regulates protein synthesis, protein folding and trafficking, cellular responses to stress and intracellular calcium $\left(\mathrm{Ca}^{2+}\right)$ levels. Alterations in $\mathrm{Ca}^{2+}$ homeostasis and accumulation of misfolded proteins in the ER cause ER stress that ultimately leads to apoptosis. Prolonged ER stress is linked to the pathogenesis of several different neurodegenerative disorders. Apoptosis is a form of cell death that involves the concerted action of a number of intracellular signaling pathways including members of the caspase family of cysteine proteases. The two main apoptotic pathways, the death receptor ('extrinsic') and mitochondrial ('intrinsic') pathways, are activated by caspase- 8 and -9 , respectively, both of which are found in the cytoplasm. Recent studies point to the ER as a third subcellular compartment implicated in apoptotic execution. Here, we review evidence for the contribution of various cellular molecules that contribute to ER stress and subsequent cellular death. It is hoped that dissection of the molecular components and pathways that alter ER structure and function and ultimately promote cellular death will provide a framework for understanding degenerative disorders that feature misfolded proteins.

Cell Death and Differentiation (2004) 11, 372-380. doi:10.1038/ sj.cdd.4401378

Published online 6 February 2004
\end{abstract}

Keywords: endoplasmic reticulum; ER stress; caspase; misfolded proteins; apoptosis; apostat

Abbreviations: ER, endoplasmic reticulum; UPR, unfolded protein response; EOR, ER-overload response; ERAD, ERassociated degradation; PKR, RNA-activated protein kinase; PERK, PKR-like ER kinase; eiF-2 alpha, eukaryotic translation initiation factor 2; GRP78/Bip, glucose-regulated protein of $78 \mathrm{kDa}$; PDI, protein disulfide isomerase; XBP1, X-box-binding protein-1; ATF-6, activating transcription factor 6; RIP, regulated intramembrane proteolysis; S1P, site 1 protease; S2P, site-2 protease; VCP, valosin-containing protein

\section{Introduction}

The endoplasmic reticulum (ER) is a principal site for protein synthesis and folding, calcium storage and calcium signaling. It also serves as a site of biosynthesis for steroids, cholesterol and other lipids. The physiological roles of the ER include regulation of protein synthesis, folding and targeting and maintenance of cellular calcium homeostasis. The ER relies on numerous resident chaperone proteins, a high level of calcium and an oxidative environment to carry out these functions efficiently. Proteins that are translocated into the ER lumen undergo post-translational modification and the folding required for optimal function. Properly folded proteins exit from the ER and progress down the secretory pathway, whereas unfolded and misfolded proteins are exported or dislocated from the ER and degraded by cytoplasmic proteasomes. $^{1-5}$

The ER is highly sensitive to alterations in calcium homeostasis and perturbations in its environment. Thus, $\mathrm{Ca}^{2+}$ ionophores that deplete calcium levels from the ER lumen, inhibitors of glycosylation, chemical toxicants, oxidative stress and/or accumulation of misfolded proteins in the ER can all disrupt ER function, resulting in what has been referred to as 'ER stress.' The ER responds by triggering specific signaling pathways including the unfolded protein response (UPR), the ER-overload response (EOR) and the ER-associated degradation (ERAD), to survive the ER stress. The overall activation of all three pathways leads to: (a) a reduction in the amount of newly synthesized protein translocated into the ER lumen, in order to reduce the load of client proteins the ER must process; (b) increased translocation and degradation of ERlocalized misfolded proteins; and (c) augmentation of the protein folding capacity of the ER.

The UPR is characterized by the coordinated activation of multiple proteins, including double-stranded RNA-activated protein kinase (PKR), the PKR-like ER kinase (PERK) and eucaryotic translation initiation factor 2 (eiF-2 alpha) kinase, all of which suppress the initiation step of protein synthesis; and by the activation of Ire1p, which triggers the expression of genes encoding ER chaperones, enzymes and structural components of the ER. The activation of the UPR may lead either to cell survival (by triggering the synthesis of ER chaperone proteins such as glucose-regulated protein of $78 \mathrm{kDa}$ (GRP78, also referred to as Bip) and protein disulfide isomerase (PDI)) or to cell demise, the latter through the activation of programmed cell death signals. The ER chaperone proteins use the energy from ATP hydrolysis to prevent protein aggregation, and maintain their associating proteins in a folding-competent state. All of these 'quality 
control mechanisms' operate to ensure that only properly folded proteins are exported from the ER lumen to the secretory pathway through the Golgi compartment. ${ }^{1,2,5-9}$

Neurodegenerative disorders such as Alzheimer's disease, Parkinson's disease, Huntington's disease, ALS (amyotrophic lateral sclerosis, or Lou Gehrig's disease) and prion protein diseases all feature misfolded proteins and the aggregation of misfolded proteins. ${ }^{10-15}$ When misfolded proteins accumulate in excessive amounts, they may overwhelm the "quality control' system designed to promote correct folding and eliminate faulty proteins, ultimately triggering cell death. ${ }^{12}$ Neurons in particular are highly susceptible to the toxic effects of misfolded proteins. ${ }^{11,12,15}$ The accumulation of misfolded proteins resulting in alterations in organelle structure, including the ER, has been observed in transgenic models of Huntington's disease, Alzheimer's disease and Lou Gehrig's disease, as well as in huntingtin-null mice. ${ }^{13,14,16-30}$ Since these same diseases may be caused by specific mutant proteins that display altered folding and degradation, it is likely that ER stress plays an important pathogenetic role in these diseases, rather than simply being a nonspecific late event in dysfunctional cells. It has been suggested that the neurotoxic species of beta-amyloid peptide in Alzheimer's disease consists of oligomers of the A-beta peptide. ${ }^{15,31}$ Similarly, Parkinson's disease is characterized by Lewy body formation; these cytoplasmic inclusions stain for alpha-synuclein, ubiquitin, proteasomal subunits ${ }^{12,15,32}$ and other components including mutant forms of Parkin and unfolded Pael receptor protein. ${ }^{33,34}$ Recent studies have shown that expanded polyglutamine tracts trigger ER stress-induced cell death. ${ }^{35-}$ 37 Murine models of mutant CuZnSOD-mediated motor neuron degeneration feature prominent intracellular inclusions in degenerating neurons and glia that stain for CuZnSOD. ${ }^{13,38}$ Misfolded proteins form insoluble aggregates and are deposited as inclusion bodies whose hydrophobic residues may permit interaction with a wide range of cellular targets to elicit cellular toxicity. ${ }^{12,14,39}$ It is believed that toxicity may arise either due to organelle dysfunction, sequestration of critical factors by the misfolded proteins, inhibition of the ubiquitin-proteasome system, energy depletion, inhibition of critical neuronal functions and/or induction of proteases such as caspases, leading to apoptosis.

Apoptosis is a form of cell death that involves the concerted action of a number of intracellular signaling pathways including members of the caspase family of cysteine proteases, which exist as (relatively) latent zymogens or procaspases. ${ }^{40}$ Oligomerization of procaspases is an important step leading to caspase activation, which in turn is amplified by the cleavage and activation of other downstream caspases. ${ }^{41,42}$ The two main apoptotic pathways, the death receptor ('extrinsic') and mitochondrial ('intrinsic') pathways (Figure 1, inset), are activated by caspase-8 (or caspase-10) and caspase-9, respectively, both of which are found in the cytoplasm. ${ }^{41}$ Caspase- 8 is recruited to a death-inducing signaling complex only when death receptors such as Fas or the tumor necrosis factor receptor bind to specific multimeric (typically trimeric) ligands (Figure 1). In contrast, caspase- 9 is activated when cytochrome $c$ is released into the cytoplasm from the mitochondrial intermembranous space (Figure 1). Activated caspase-8 and -9 activate executioner

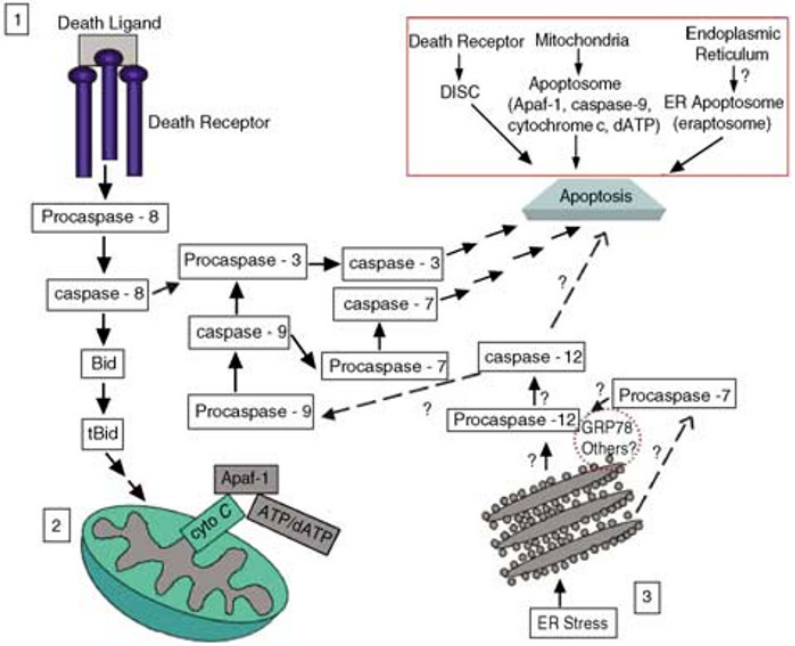

Figure 1 Three signaling pathways that trigger apoptosis (inset). (1) Binding of death receptors (Fas or the tumor necrosis factor receptors) to specific multimeric (typically trimeric) ligands results in the recruitment of adaptor molecules involved in the activation of caspase-8. (2) When the mitochondrion receives appropriate apoptotic signals, cytochrome $c$ and other molecules are released into the cytosol. Cytochrome $c$ forms a complex with Apaf-1 and (d)ATP, and activates procaspase-9. (3) Alterations in $\mathrm{Ca}^{2+}$ homeostasis and accumulation of misfolded proteins in the ER cause ER stress. Prolonged ER stress can result in the activation of caspase-12 that may feed back into a caspase-9-dependent loop and execute apoptosis. The solid arrows indicate known pathways. The dashed arrows and question marks denote possible but unconfirmed interactions and pathways. The dashed closed circle indicates possible interaction

caspases, including caspase-3. Once active, executioner caspases cleave a number of cellular proteins that include nuclear proteins, structural proteins, signaling molecules, cytoskeletal proteins and other proteins implicated in neurodegenerative disease. ${ }^{41,43}$ Proteolysis of these proteins disrupts cellular homeostasis and terminates survival signals, among other effects.

Studies from multiple laboratories including ours point to the ER as a third subcellular compartment implicated in apoptotic execution (Figure 1, inset). Like the mitochondria, the ER is a repository for both proapoptotic and antiapoptotic molecules (Figure 1). The known proapoptotic molecules include caspase-12, ${ }^{44-46}$ p28Bap31 ${ }^{47}$ and GADD153 ${ }^{1}$, while the antiapoptotic molecules identified to date include the ER chaperone proteins GRP78, calreticulin, ${ }^{48} \mathrm{PDI}$ and ORP$150,{ }^{1,49,50}$ as well as DAD1. ${ }^{51,52}$ In addition, a significant fraction of endogenous Bcl-2 family members including $\mathrm{Bcl}-2$, $\mathrm{Bcl}-\mathrm{x}_{\mathrm{L}}, \mathrm{Bax}, \mathrm{Bak}$ and Bik have been shown to be associated with the $\mathrm{ER}$, suggesting that Bcl-2 family proteins operate at the ER (at least in part) to regulate calcium homeostasis and apoptotic cell death. ${ }^{47,53,54-57}$ Here, we review evidence for the molecular components involved in cell death signaling induced by ER stress. Based on their actions in response to ER stress, these molecular components may be classified as sensors, modulators or effectors (Figure 2).

\section{ER stress-induced cell death: sensors}

Although the UPR-signaling pathway was first described in the budding yeast Saccharomyces cerevisiae, eucaryotic cells 


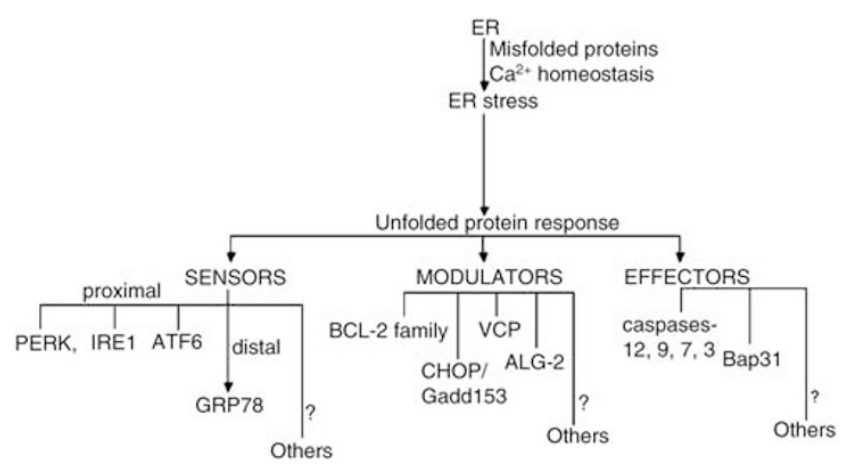

Figure 2 Alterations in calcium homeostasis and/or accumulation of misfolded proteins in the ER can all disrupt ER function resulting in 'ER stress'. The ER responds by triggering specific signaling pathways including the UPR. Prolonged ER stress leads to organelle damage and dysfunction and ultimately leads to cell death. The molecular components involved in the UPR leading to cell survival or cell death signaling can be classified as sensors, modulators or effectors. The balance between various modulators determines ER stress-induced cell survival versus death

also appear to have maintained the essential and unique properties of the UPR. In addition, higher eucaryotes also possess additional sensors that coordinate and regulate stress adaptation or cell death responses. PERK, IRE1 and activating transcription factor (ATF-6) serve as proximal sensors that regulate components that act to upregulate the capacity of the ER to fold newly synthesized proteins and degrade misfolded/unfolded proteins. ${ }^{1,5,7,8,58}$

Changes in the ER environment due to the accumulation of misfolded proteins or due to disruption of calcium homeostasis trigger the UPR. In turn, the UPR triggers two downstream signal transduction events: the induction of genes coding for ER-resident stress proteins and the suppression of initiation of protein synthesis., ${ }^{4,7}$ The ERresident protein kinase PERK has been implicated in the latter process. In normal unstressed cells, the binding of the ER chaperone protein GRP78 to the lumenal domain of PERK keeps it (PERK) in an inactive conformation. As misfolded proteins accumulate, the GRP78-PERK complex is disrupted, and PERK undergoes oligomerization and transautophosphorylation. ${ }^{59}$ The kinase domain of the activated phosphorylated PERK phosphorylates the alpha subunit of eucaryotic translation initiation factor-2 alpha (elF2 $\alpha$ ), thereby attenuating translation initiation and protein synthesis. Cells that lack PERK cannot induce the UPR, and are therefore extremely sensitive to ER stress-inducing agents, probably due to the accumulation of misfolded proteins and an overall failure in responding to ER stress. PERK activation and elF2 $\alpha$ phosphorylation lead to: (a) a decrease in protein folding load in the ER; (b) induction of the expression of elF2 $\alpha$ phosphorylation-dependent ER stress genes; and (c) promotion of cell survival. ${ }^{7,60-64}$

IRE1 was first identified as an ER membrane-spanning receptor protein kinase required for inositol phototrophy. ${ }^{65-67}$ Later studies identified it as a sensor of misfolded/unfolded proteins in the ER lumen. The IRE1 gene encodes an 1115 amino-acid, type 1 transmembrane Ser/Thr receptor protein kinase that also possesses site-specific endoribonuclease
(RNase) activity. The receptor protein has an amino-terminal signal peptide, an amino-terminal domain that localizes it to the ER lumen, a short transmembrane domain and a carboxyterminal cytoplasmic domain with kinase activity. The lumenal domain of IRE1 has a significant similarity to the PERK protein, and is negatively regulated by GRP78. ${ }^{59}$ The presence of misfolded/unfolded proteins in the ER lumen promotes dissociation of the GRP78-IRE1 complex, dimerization and trans-autophosphorylation of IRE1, rendering IRE1 active as an RNase, and allowing it to cleave a preformed substrate mRNA at two sites, resulting in the removal of a 252-base intron from the target mRNA. ${ }^{68-70}$ The two ends of the cleaved mRNA are ligated together by tRNA ligase and the newly formed mRNA encodes a transcription factor, HAC1p, that can bind and activate the promoters of several ER stress-inducible target genes. ${ }^{71,72}$ Two Ire1 isoforms, IRE $1 \alpha$ and $I R E 1 \beta$, have been identified in the mammalian genome. Sequence comparisons show that the C-terminal kinase and endoribonuclease domains are more conserved among all known Ire1 homologs, while the ERlumenal domains are more divergent. ${ }^{73-75} I R E 1 \alpha$ is expressed in most cells and tissues, with high-level expression in the pancreas and placenta. The expression of IRE $1 \beta$ is prominent only in intestinal epithelial cells. ${ }^{73,74}$ The overexpression of either isoform induces the UPR that is blocked by the overexpression of its dominant-negative forms. Both IRE1 molecules respond to the accumulation of unfolded proteins in the ER, undergo kinase activation and, thereby, trigger their RNase activities. X-box-binding protein-1 (XBP1) mRNA is a substrate for mammalian IRE1, is processed similarly to yeast Hac1p, and the resulting processed mRNA encodes a novel and potent transcriptional activator. ${ }^{76,77}$

Yet another proximal ER stress sensor, activating transcription factor 6 (ATF6), ${ }^{76}$ is activated by regulated intramembrane proteolysis (RIP). ${ }^{78}$ In unstressed cells, ATF6 is present as an inactive protein associated with the ER membrane, and it is negatively regulated by GRP78. As misfolded proteins accumulate, GRP78 is released from ATF6, permitting the transport of ATF6 to the Golgi, where it is cleaved by site-1 protease (S1P) and site-2 protease (S2P). Proteolysis by S1P and S2P liberates the amino-terminal portion of ATF6 that migrates to the nucleus, binds ER stress elements in the promoter of UPR-responsive genes and triggers the expression of ER stress-inducible target genes. ${ }^{79-84}$ There are two forms of ATF6: ATF6 $\alpha$ (90 kDa) and ATF $6 \beta(110 \mathrm{kDa})$. Both forms are under RIP control and on activation of the UPR are processed to generate 50- to 60$\mathrm{kDa}$ cytosolic protein fragments that migrate to the nucleus and activate target genes.

The glucose-regulated proteins or GRPs were initially identified as a family of $\mathrm{Ca}^{2+}$-binding chaperone proteins whose transcription was induced during viral transformation or glucose deprivation. Subsequently, based on several reports, it became clear that the expression of GRPs is induced in response to several stimuli including oxidative stress, chemical toxicity, treatment with $\mathrm{Ca}^{2+}$ ionophores and exposure to inhibitors of glycosylation that disrupt ER structure and function. ${ }^{1,85}$ GRP78 (Bip) is one the bestcharacterized ER chaperone proteins, and it has served as a classical marker for UPR activation. The induction of GRP78 
is required to alleviate ER stress, maintain ER function, facilitate protein folding and protect cells from the aforementioned toxic insults. ${ }^{1}$ GRP78 functions as a master regulator of the UPR by binding to, and preventing the activation of, all three proximal stress sensors (under nonstressed conditions): IRE1, PERK and ATF6. When misfolded proteins accumulate in the cell, they bind to GRP78 and disrupt its interaction with the stress sensors, resulting in their activation. GRP78 also binds transiently to the exposed hydrophobic residues of nascent folded proteins, ensures proper protein folding and prevents protein aggregation. In addition, studies from several laboratories suggest that GRP78 may also protect the host cell against cell death by suppressing oxyradical accumulation and stabilizing mitochondrial function. ${ }^{86-89}$

While GRP78 exists as an ER lumen protein, ${ }^{1,85}$ several reports have suggested that GRP78 (and several mutants derived therefrom) may also redistribute to the cytosol, nucleus and cell surface, as well as establishing a microsomal subpopulation that is partially protease sensitive. ${ }^{90-96}$ This latter effect suggests that, under stress conditions, GRP78 may also exist as an ER transmembrane protein (although how transient this effect is, is not clear). The potential explanations for the presence of GRP78 outside the ER are: (a) saturation of KDEL receptors in the $E R$, resulting in targeting overflow; (b) interactions with other proteins or lipids that consequently hinder binding to the KDEL receptor, allowing GRP78 egress from the ER; or (c) an active release from intact cells during cellular stress. ${ }^{94,97,98}$ This phenomenon was also observed with calreticulin, an ER-lumenal protein that redistributes from the ER and appears in the cytosol during heat stress. ${ }^{99,100}$ Similarly, a subpopulation of GRP94 associates with the ER membrane during an apoptotic insult, where it becomes a target of calpain activity. ${ }^{101}$ Recent studies have also suggested that either a cytosolic pool of GRP78 or a subpopulation of GRP78 existing as an ER transmembrane protein may form a complex with caspase-7 and -12 at the ER surface, and prevent their activation and release. ${ }^{95,96}$ These studies highlight the importance of GRP78 as an antiapoptotic protein, and shed new light on the mechanisms underlying the relationship between ER stress, the UPR and the cell death program.

Despite the efficient 'ER quality control mechanisms' that exist to respond to any disturbances that affect ER structure, function and integrity, prolonged ER stress ultimately leads to cell death. While the mechanisms underlying ER stressinduced cell death are not clear, recent studies have identified genes that trigger cell death pathways during prolonged ER stress. Coupling ER stress to the cell death program(s) may be advantageous to the organism not only by destroying damaged, dysfunctional cells but also as part of a recycling mechanism to allow recovery of organ function. . $^{3,4}$

\section{ER stress-induced cell death: modulators}

The roles of several ER stress-induced cell death modulators and effectors have been revealed by biochemical, pharmacological and genetic tools. The ER stress-induced cell death modulators include (but are not limited to) members of the Bcl2 family (Bcl-2, Bcl- $x_{\mathrm{L}}$, Bax, Bak and Bik), CHOP/Gadd153, valosin-containing protein (VCP) and apoptosis linked gene-2 (ALG-2).

One of the first genes to be identified as a modulator of cell death was $b c /-2 .^{102-108} \mathrm{Bcl}-2$ proteins and their apparent roles in cell death have been evolutionarily conserved, and these proteins play key roles in regulating the integrity of the ER and mitochondrial membranes. ${ }^{109-112}$ The Bcl-2 family can be either proapoptotic (e.g., Bax, Bak) or antiapoptotic (e.g., Bcl2 , Bcl- $\left.x_{\mathrm{L}}\right)$, and based on their protein structures the proapoptotic proteins are classified into multidomain proteins (e.g., Bax, Bak) and BH3-only proteins (e.g., Bad, Bid, Bim, Bik). ${ }^{112,113}$ On activation, the proapoptotic Bax and Bak proteins form protein-conducting channels in the mitochondrial outer membrane, causing release of proapoptotic proteins such as cytochrome $c$; the latter then binds to the adaptor protein Apaf-1 and the initiator caspase-9, resulting in a downstream proteolytic cascade. This cascade leads to the cleavage of specific cellular proteins as well as DNA, and is attended by the demise of the cell. Antiapoptotic Bcl-2 members inhibit apoptosis by: (a) binding and sequestering activated Bak and Bax, thus preventing pore formation; and/or (b) sequestering the $\mathrm{BH} 3$-only members that would otherwise displace the antiapoptotic $\mathrm{Bcl}-2$ family proteins from the proapoptotic ones such as Bax and Bak, which would in that case become active. ${ }^{57,111,114}$ A significant fraction of endogenous Bcl-2 family member proteins including $\mathrm{Bcl}-2$, Bcl$\mathrm{x}_{\mathrm{L}}$, Bax, Bak and Bik has been shown to be associated with the ER, ${ }^{55-57,111,114}$ where, among other potential effects, these proteins function in the maintenance of $\mathrm{Ca}^{2+}$ homeostasis. The overexpression of Bax or Bak leads to $\mathrm{Ca}^{2+}$ efflux from the $\mathrm{ER}, \mathrm{Ca}^{2+}$ influx into the mitochondria and increased cytochrome $c$ release-induced $\mathrm{ER} \mathrm{Ca}^{2+}$ efflux, leading to cell death that is inhibitable by $\mathrm{Bcl}-2 .^{115,116} \mathrm{Bax} / \mathrm{Bak}$ doubly deficient mouse embryonic fibroblasts are resistant to both mitochondrial-mediated apoptosis and ER stress stimuli, suggesting a possible crosstalk between ER and mitochondrial cell death pathways. ${ }^{56,112}$ The ER-mitochondria crosstalk may be utilized for mitochondrial amplification of ERinitiated apoptotic pathways, or for other pathways. In any case, the balance between these various $\mathrm{Bcl}-2$ family members determines an 'apoptotic rheostat' or 'apostat' that modulates ER-mitochondrial-dependent cell survival versus death. ${ }^{42,117-119}$

Another ER stress-induced cell death modulator is CHOP/ Gadd153, a transcription factor induced during ER stress and subsequently activated by p38 mitogen-associated protein kinase. $^{1,7,63,120}$ Several reports suggest that CHOP negatively regulates cell growth and promotes ER stress-induced apoptosis. ${ }^{1,121,122}$ Gadd153 overexpression promotes cell death, but the overexpression of GRP78 blocks Gadd153mediated cell cycle arrest and apoptosis. ${ }^{120,123}$ The deletion of the $C H O P$ gene leads to an attenuation in cell death induced by ER stress. ${ }^{124,125}$ While the identification of the downstream target genes that respond to $\mathrm{CHOP} /$ Gadd153 is still unclear, it has been suggested that Gadd153 may promote ER stress-induced cell death by downregulating Bcl-2 expression. ${ }^{125}$

Recent data have implicated two additional proteins ${ }^{126}$ that, together with caspase-12, caspase-9, caspase-7, ATP and $\mathrm{Ca}^{2+}$, appear to function as mediators of ER stress-induced 
cell death. One of these, VCP, is a member of the AAA (ATPases associated with diverse cellular activities) family of ATP-binding, homo-oligomeric ATPase proteins, and participates in multiple cellular activities by binding to several targetspecific adaptors. These cellular activities include vesicle transport and fusion, 26S proteasome function, assembly of peroxisomes, membrane transport processes and ubiquitinproteasome degradation. ${ }^{127-129}$ VCP also functions as a sensor of abnormally folded proteins (and therefore may also be appropriately included in the group of sensors above) and has been reported to act as a cell death effector in polyglutamine-induced cell death. ${ }^{130,131}$

ALG-2 is a low molecular weight $(22 \mathrm{kDa}) \mathrm{Ca}^{2+}$-binding protein that possesses strong apoptosis-inducing activity and is involved in T-cell receptor-, Fas- and glucocorticoid-induced cell death. ALG-2 translocates from the membrane compartment to the cytosol during Fas-mediated apoptosis and ALG-2 depletion blocks programmed cell death induced by several stimuli, such as synthetic glucocorticoids, T-cell receptor ligation and Fas ligand. ${ }^{132-135}$

Coimmunoprecipitation studies have suggested that both VCP and ALG-2 may function as part of an ER stress-induced caspase-activating complex, that is, an ER-based apoptosome or 'eraptosome'126, (Figure 1); this would be compatible with previous reports that caspase-12 zymogen may be identified as part of a complex with a relative molecular mass greater than $600 \mathrm{kD} .^{136,137}$

However, additional studies will be required to determine whether this putative complex does indeed include VCP and/ or ALG-2, and, if so, what role these modulators play in caspase activation induced by ER stress.

\section{ER stress-induced cell death: effectors}

Several molecules either present on the ER surface or in the soluble compartment have been implicated as effectors that cause cell death in response to prolonged ER stress. Caspase-12 (a murine caspase not yet unequivocally identified in human tissue), which is associated with the ER, is specifically involved in apoptosis that results from ER stress. ${ }^{44-46,95,138}$ The activation of caspase-12 may occur through ER stress-induced calpain or caspase-7 cleavage of procaspase-12. ${ }^{46,138}$ ER stress-activated IRE1 may also aggregate procaspase-12 at the ER membrane surface through the cytosolic adaptor TRAF2 proteins, resulting in the cleavage and activation of caspase-12, ${ }^{139}$ presumably via an induced proximity mechanism. Caspase-12, together with caspase-9, serves as a mediator of a novel intrinsic apoptosis pathway that is independent of Apaf-1, cytochrome $c$ and mitochondria (this is not to say that mitochondria may not be involved in the amplification of this pathway, simply that they are not required for its activation). ${ }^{138,140,141}$ It is worth noting that caspase-12 was identified in the murine system, and its presence in human tissues is controversial; however, antibodies directed against mouse caspase- 12 crossreact with a human cellular protein that is of similar relative molecular mass to that of mouse caspase-12, and is cleaved similarly to murine caspase-12. ${ }^{44-46,142}$ This human caspase-12 candidate has been shown not to be one of the previously described human caspases (Rao et al., unpublished data). Although the human genome has not revealed a clear caspase-12 candidate, one group has reported a human caspase-12 sequence; ${ }^{143}$ however, this putative caspase- 12 sequence is predicted to encode a protein that has a significant deletion, so that it would be highly unlikely to demonstrate a molecular mass similar to the murine caspase- 12 .

BAP31 is an ER transmembrane protein that binds to nascent membrane proteins in transit between ER and cisGolgi, and exists in a complex with procaspase-8 and the antiapoptotic regulator $\mathrm{Bcl}-2$ or $\mathrm{Bcl}-\mathrm{x}_{\mathrm{L}}$. ER stress and other apoptotic signals lead to the cleavage of BAP31, giving rise to a p20 fragment that causes the following: (a) early release of $\mathrm{Ca}^{2+}$ from the ER; (b) uptake of $\mathrm{Ca}^{2+}$ into mitochondria; and (c) induction of cytochrome $c$ release, caspase activation and apoptosis. Furthermore, caspase-8 cleavage of BAP31 at the ER stimulates $\mathrm{Ca}^{2+}$-dependent mitochondrial fission, enhancing the release of cytochrome $c$ in response to this initiator caspase. Thus the caspase-derived fragment of Bap31 may be a coordinator of cell death signals between the ER and mitochondria. ${ }^{53,114,144-147}$

\section{Conclusions}

The ER is very sensitive to changes in its environment leading to disruption of its normal homeostasis. A variety of environmental insults (leading, for example, to changes in $\mathrm{Ca}^{2+}$ homeostasis), as well as genetic diseases associated with the accumulation of misfolded proteins, can all affect the ER structure, function and integrity, leading to ER stress and contributing to the pathogenesis of different disease states. Prolonged stress leads to organelle damage and dysfunction, and ultimately to cell death. The accumulation of misfolded proteins seen in various neurodegenerative diseases leads to an ER stress response, irrespective of whether the misfolded proteins build up within the ER or outside the ER. It is thus important to define the biochemical pathways by which ER stress induces programmed cell death, since an understanding of the relationship between the accumulation of misfolded proteins, cellular stress responses and cell death programs should facilitate the development of new therapeutic strategies for degenerative disorders that feature misfolded proteins.

\section{Acknowledgements}

The work in this laboratory is supported by the National Institutes of Health (AG12282 to DEB; NS33376 to DEB and RVR; and CA84262 to HME), the Department of Defense (DAMDI17-98-8613 to DEB) and by a grant to the Buck Institute from American Bioscience, Inc.

\section{References}

1. Kaufman RJ (1999) Stress signaling from the lumen of the endoplasmic reticulum: coordination of gene transcriptional and translational controls. Genes Dev. 13: 1211-1233

2. Welihinda AA, Tirasophon W and Kaufman RJ (1999) The cellular response to protein misfolding in the endoplasmic reticulum. Gene Expr. 7: 293-300 
3. Kaufman RJ, Scheuner D, Schroder M, Shen X, Lee K, Liu CY and Arnold SM (2002) The unfolded protein response in nutrient sensing and differentiation. Nat. Rev. Mol. Cell. Biol. 3: 411-421

4. Kaufman RJ (2002) Orchestrating the unfolded protein response in health and disease. J. Clin. Invest. 110: 1389-1398

5. Ma Y and Hendershot LM (2002) The mammalian endoplasmic reticulum as a sensor for cellular stress. Cell Stress Chaperones 7: 222-229

6. Ron D (2002) Translational control in the endoplasmic reticulum stress response. J. Clin. Invest. 110: 1383-1388

7. Harding HP, Calfon M, Urano F, Novoa I and Ron D (2002) Transcriptional and translational control in the mammalian unfolded protein response. Annu. Rev. Cell Dev. Biol. 18: 575-599

8. Paschen W and Frandsen A (2001) Endoplasmic reticulum dysfunction - a common denominator for cell injury in acute and degenerative diseases of the brain? J. Neurochem. 79: 719-725

9. Paschen W and Doutheil J (1999) Disturbance of endoplasmic reticulum functions: a key mechanism underlying cell damage? Acta Neurochir. Suppl. 73: $1-5$

10. Kopito RR (2000) Aggresomes, inclusion bodies and protein aggregation Trends Cell Biol. 10: 524-530

11. Sherman MY and Goldberg AL (2001) Cellular defenses against unfolded proteins: a cell biologist thinks about neurodegenerative diseases. Neuron 29 : 15-32

12. Taylor JP, Hardy J and Fischbeck KH (2002) Toxic proteins in neurodegenerative disease. Science 296: 1991-1995

13. Cleveland DW and Rothstein JD (2001) From Charcot to Lou Gehrig: deciphering selective motor neuron death in ALS. Nat. Rev. Neurosci. 2: 806819

14. Julien JP (2001) Amyotrophic lateral sclerosis. unfolding the toxicity of the misfolded. Cell 104: 581-591

15. Martin JB (1999) Molecular basis of the neurodegenerative disorders. N. Engl. J. Med. 340: 1970-1980

16. Dal Canto MC and Gurney ME (1994) Development of central nervous system pathology in a murine transgenic model of human amyotrophic lateral sclerosis. Am. J. Pathol. 145: 1271-1279

17. Guidetti $\mathrm{P}$, Charles V, Chen EY, Reddy PH, Kordower JH, Whetsell Jr WO, Schwarcz R and Tagle DA (2001) Early degenerative changes in transgenic mice expressing mutant huntingtin involve dendritic abnormalities but no impairment of mitochondrial energy production. Exp. Neurol. 169: 340-350

18. Higgins $\mathrm{CM}$, Jung $\mathrm{C}$, Ding $\mathrm{H}$ and $\mathrm{Xu} Z$ (2002) Mutant $\mathrm{Cu}$, Zn superoxide dismutase that causes motoneuron degeneration is present in mitochondria in the CNS. J. Neurosci. 22: RC215

19. Hilditch-Maguire $P$, Trettel F, Passani LA, Auerbach A, Persichetti $F$ and MacDonald ME (2000) Huntingtin: an iron-regulated protein essential for normal nuclear and perinuclear organelles. Hum. Mol. Genet. 9: 2789-2797

20. Hodgson JG, Agopyan N, Gutekunst CA, Leavitt BR, LePiane F, Singaraja R Smith DJ, Bissada N, McCutcheon K, Nasir J, Jamot L, Li XJ, Stevens ME, Rosemond E, Roder JC, Phillips AG, Rubin EM, Hersch SM and Hayden MR (1999) A YAC mouse model for Huntington's disease with full-length mutant huntingtin, cytoplasmic toxicity, and selective striatal neurodegeneration. Neuron 23: 181-192

21. Iannicola C, Moreno S, Oliverio S, Nardacci R, Ciofi-Luzzatto A and Piacentini $M(2000)$ Early alterations in gene expression and cell morphology in a mouse model of Huntington's disease. J. Neurochem. 75: 830-839

22. Mattson MP, Chan SL and Camandola S (2001) Presenilin mutations and calcium signaling defects in the nervous and immune systems. BioEssays 23 : 733-744

23. Lyons TJ, Liu H, Goto JJ, Nersissian A, Roe JA, Graden JA, Cafe C, Ellerby LM, Bredesen DE, Gralla EB and Valentine JS (1996) Mutations in copperzinc superoxide dismutase that cause amyotrophic lateral sclerosis alter the zinc binding site and the redox behavior of the protein. Proc. Natl. Acad. Sci. USA 93: 12240-12244

24. Martindale $D$, Hackam A, Wieczorek A, Ellerby L, Wellington $C$, McCutcheon K, Singaraja R, Kazemi-Esfariani P, Devon R, Kim SU, Bredesen DE, Tufaro F and Hayden MR (1998) Length of huntingtin and its polyglutamine tract influences localization and frequency of intracellular aggregates. Nat. Genet. 18: $150-154$

25. Nasir J, Floresco SB, O'Kusky JR, Diewert VM, Richman JM, Zeisler J Borowski A, Marth JD, Philips AG and Hayden MR (1995) Targeted disruption of the Huntington's disease gene results in embryonic lethality and behavioral and morphological changes in heterozygotes. Cell 81: 811-823

26. Reddy PH, Williams M and Tagle DA (1999) Recent advances in understanding the pathogenesis of Huntington's disease. Trends Neurosci. 22: 248-255

27. Tabrizi SJ, Workman J, Hart PE, Mangiarini L, Mahal A, Bates G, Cooper JM and Schapira AH (2000) Mitochondrial dysfunction and free radical damage in the Huntington R6/2 transgenic mouse. Ann. Neurol. 47: 80-86

28. Turmaine M, Raza A, Mahal A, Mangiarini L, Bates GP and Davies SW (2000) Nonapoptotic neurodegeneration in a transgenic mouse model of Huntington's disease. Proc. Natl. Acad. Sci. USA 97: 8093-8097

29. White JK, Auerbach W, Duyao MP, Vonsattel JP, Gusella JF, Joyner AL and MacDonald ME (1997) Huntingtin is required for neurogenesis and is not impaired by the Huntington's disease CAG expansion. Nat. Genet. 17: 404410

30. Wiedau-Pazos M, Goto JJ, Rabizadeh S, Gralla EB, Roe JA, Lee MK, Valentine JS and Bredesen DE (1996) Altered reactivity of superoxide dismutase in familial amyotrophic lateral sclerosis [see comments]. Science 271: 515-518

31. Glabe C (2001) Intracellular mechanisms of amyloid accumulation and pathogenesis in Alzheimer's disease. J. Mol. Neurosci. 17: 137-145

32. Kakizuka A (1998) Protein precipitation: a common etiology in neurodegenerative disorders? Trends Genet. 14: 396-402

33. Farrer M, Chan P, Chen R, Tan L, Lincoln S, Hernandez D, Forno L, GwinnHardy K, Petrucelli L, Hussey J, Singleton A, Tanner C, Hardy J and Langston JW (2001) Lewy bodies and parkinsonism in families with Parkin mutations. Ann. Neurol. 50: 293-300

34. Imai Y, Soda M, Inoue H, Hattori N, Mizuno Y and Takahashi R (2001) An unfolded putative transmembrane polypeptide, which can lead to endoplasmic reticulum stress, is a substrate of Parkin. Cell 105: 891-902

35. Kouroku Y, Fujita E, Jimbo A, Kikuchi T, Yamagata T, Momoi MY, Kominami E, Kuida K, Sakamaki K, Yonehara S and Momoi T (2002) Polyglutamine aggregates stimulate ER stress signals and caspase-12 activation. Hum. Mol. Genet. 11: 1505-1515

36. Matsuzawa A, Nishitoh H, Tobiume K, Takeda K and Ichijo H (2002) Physiological roles of ASK1-mediated signal transduction in oxidative stressand endoplasmic reticulum stress-induced apoptosis: advanced findings from ASK1 knockout mice. Antioxid. Redox Signal. 4: 415-425

37. Nishitoh H, Matsuzawa A, Tobiume K, Saegusa K, Takeda K, Inoue K, Hori S, Kakizuka A and Ichijo H (2002) ASK1 is essential for endoplasmic reticulum stress-induced neuronal cell death triggered by expanded polyglutamine repeats. Genes Dev. 16: 1345-1355

38. Williamson TL, Corson LB, Huang L, Burlingame A, Liu J, Bruijn LI and Cleveland DW (2000) Toxicity of ALS-linked SOD1 mutants. Science 288: 399

39. Auluck PK, Chan HY, Trojanowski JQ, Lee VM and Bonini NM (2002) Chaperone suppression of alpha-synuclein toxicity in a Drosophila model for Parkinson's disease. Science 295: 865-868

40. Martin SJ and Green DR (1995) Protease activation during apoptosis: death by a thousand cuts? Cell 82: 1-20

41. Earnshaw WC, Martins LM and Kaufmann SH (1999) Mammalian caspases: structure, activation, substrates, and functions during apoptosis. Annu. Rev. Biochem. 68: 383-424

42. Salvesen GS and Dixit VM (1997) Caspases: intracellular signaling by proteolysis. Cell 91: 443-446

43. Stroh C and Schulze-Osthoff K (1998) Death by a thousand cuts: an ever increasing list of caspase substrates. Cell Death Differ. 5: 997-1000

44. Rao RV, Hermel E, Castro-Obregon S, del Rio G, Ellerby LM, Ellerby HM and Bredesen DE (2001) Coupling endoplasmic reticulum stress to the cell death program. Mechanism of caspase activation. J. Biol. Chem. 276: 33869-33874

45. Nakagawa T and Yuan J (2000) Cross-talk between two cysteine protease families. Activation of caspase-12 by calpain in apoptosis. J. Cell Biol. 150: 887-894

46. Nakagawa T, Zhu H, Morishima N, Li E, Xu J, Yankner BA and Yuan J (2000) Caspase-12 mediates endoplasmic-reticulum-specific apoptosis and cytotoxicity by amyloid-beta. Nature 403: 98-103

47. Ng FW, Nguyen M, Kwan T, Branton PE, Nicholson DW, Cromlish JA and Shore GC (1997) p28 Bap31, a Bcl-2/Bcl-XL- and procaspase-8-associated protein in the endoplasmic reticulum. J. Cell Biol. 139: 327-338 
48. Ozawa K, Kuwabara K, Tamatani M, Takatsuji K, Tsukamoto Y, Kaneda S, Yanagi H, Stern DM, Eguchi Y, Tsujimoto Y, Ogawa S and Tohyama M (1999) 150-kDa oxygen-regulated protein (ORP150) suppresses hypoxia-induced apoptotic cell death. J. Biol. Chem. 274: 6397-6404

49. Liu H, Bowes III RC, van de Water B, Sillence C, Nagelkerke JF and Stevens $\mathrm{JL}$ (1997) Endoplasmic reticulum chaperones GRP78 and calreticulin prevent oxidative stress, $\mathrm{Ca}^{2+}$ disturbances, and cell death in renal epithelial cells. J. Biol. Chem. 272: 21751-21759

50. Tanaka S, Uehara T and Nomura Y (2000) Up-regulation of protein-disulfide isomerase in response to hypoxia/brain ischemia and its protective effect against apoptotic cell death. J. Biol. Chem. 275: 10388-10393

51. Brewster JL, Martin SL, Toms J, Goss D, Wang K, Zachrone K, Davis A, Carlson G, Hood L and Coffin JD (2000) Deletion of Dad1 in mice induces an apoptosis-associated embryonic death. Genesis 26: 271-278

52. Hong NA, Flannery M, Hsieh SN, Cado D, Pedersen R and Winoto A (2000) Mice lacking Dad1, the defender against apoptotic death-1, express abnormal $\mathrm{N}$-linked glycoproteins and undergo increased embryonic apoptosis. Dev. Biol. 220: 76-84

53. Breckenridge DG, Nguyen M, Kuppig S, Reth M and Shore GC (2002) The procaspase-8 isoform, procaspase-8L, recruited to the BAP31 complex at the endoplasmic reticulum. Proc. Natl. Acad. Sci. USA 99: 4331-4336

54. Germain M, Mathai JP and Shore GC (2002) BH-3-only BIK functions at the endoplasmic reticulum to stimulate cytochrome $c$ release from mitochondria. J. Biol. Chem. 277: 18053-18060

55. Scorrano L, Oakes SA, Opferman JT, Cheng EH, Sorcinelli MD, Pozzan T and Korsmeyer SJ (2003) BAX and BAK regulation of endoplasmic reticulum $\mathrm{Ca}^{2+}$ : a control point for apoptosis. Science $300: 135-139$

56. Wei MC, Zong WX, Cheng EH, Lindsten T, Panoutsakopoulou V, Ross AJ, Roth KA, MacGregor GR, Thompson CB and Korsmeyer SJ (2001) Proapoptotic BAX and BAK: a requisite gateway to mitochondrial dysfunction and death. Science 292: 727-730

57. Germain M and Shore GC (2003) Cellular distribution of Bcl-2 family proteins. Sci. STKE 2003: pe10

58. Pahl HL (1999) Signal transduction from the endoplasmic reticulum to the cell nucleus. Physiol. Rev. 79: 683-701

59. Bertolotti A, Zhang Y, Hendershot LM, Harding HP and Ron D (2000) Dynamic interaction of BiP and ER stress transducers in the unfolded-protein response. Nat. Cell. Biol. 2: 326-332

60. Shi Y, Vattem KM, Sood R, An J, Liang J, Stramm L and Wek RC (1998) Identification and characterization of pancreatic eukaryotic initiation factor 2 alpha-subunit kinase, PEK, involved in translational control. Mol. Cell. Biol. 18: 7499-7509

61. Harding HP, Zhang $Y$ and Ron D (1999) Protein translation and folding are coupled by an endoplasmic-reticulum-resident kinase. Nature 397: $271-274$

62. Liu CY, Schroder M and Kaufman RJ (2000) Ligand-independent dimerization activates the stress response kinases IRE1 and PERK in the lumen of the endoplasmic reticulum. J. Biol. Chem. 275: 24881-24885

63. Harding HP, Novoa I, Zhang Y, Zeng H, Wek R, Schapira M and Ron D (2000) Regulated translation initiation controls stress-induced gene expression in mammalian cells. Mol. Cell 6: 1099-1108

64. Scheuner D, Song B, McEwen E, Liu C, Laybutt R, Gillespie P, Saunders T, Bonner-Weir $S$ and Kaufman RJ (2001) Translational control is required for the unfolded protein response and in vivo glucose homeostasis. Mol. Cell 7: $1165-1176$

65. Nikawa J and Yamashita S (1992) IRE1 encodes a putative protein kinase containing a membrane-spanning domain and is required for inositol phototrophy in Saccharomyces cerevisiae. Mol. Microbiol. 6: 1441-1446

66. Cox JS, Shamu CE and Walter P (1993) Transcriptional induction of genes encoding endoplasmic reticulum resident proteins requires a transmembrane protein kinase. Cell 73: 1197-1206

67. Mori K, Ma W, Gething MJ and Sambrook J (1993) A transmembrane protein with a cdc2+/CDC28-related kinase activity is required for signaling from the ER to the nucleus. Cell 74: 743-756

68. Sidrauski $C$ and Walter $P(1997)$ The transmembrane kinase Ire1p is a sitespecific endonuclease that initiates mRNA splicing in the unfolded protein response. Cell 90: 1031-1039

69. Kawahara T, Yanagi H, Yura T and Mori K (1997) Endoplasmic reticulum stress-induced mRNA splicing permits synthesis of transcription factor
Hac1p/Ern4p that activates the unfolded protein response. Mol. Cell. Biol. 8: 1845-1862

70. Patil $C$ and Walter $P$ (2001) Intracellular signaling from the endoplasmic reticulum to the nucleus: the unfolded protein response in yeast and mammals. Curr. Opin. Cell Biol. 13: 349-355

71. Sidrauski $C$, Cox JS and Walter $P$ (1996) tRNA ligase is required for regulated mRNA splicing in the unfolded protein response. Cell 87: 405-413

72. Mori K, Ogawa N, Kawahara T, Yanagi H and Yura T (2000) mRNA splicingmediated C-terminal replacement of transcription factor Hac1p is required for efficient activation of the unfolded protein response. Proc. Natl. Acad. Sci. USA 97: 4660-4665

73. Wang XZ, Harding HP, Zhang Y, Jolicoeur EM, Kuroda M and Ron D (1998) Cloning of mammalian Ire1 reveals diversity in the ER stress responses. EMBO J. 17: $5708-5717$

74. Tirasophon W, Welihinda AA and Kaufman RJ (1998) A stress response pathway from the endoplasmic reticulum to the nucleus requires a nove bifunctional protein kinase/endoribonuclease (Ire1p) in mammalian cells. Genes Dev. 12: 1812-1824

75. Niwa M, Sidrauski C, Kaufman RJ and Walter P (1999) A role for presenilin-1 in nuclear accumulation of Ire1 fragments and induction of the mammalian unfolded protein response. Cell 99: 691-702

76. Yoshida H, Haze K, Yanagi H, Yura T and Mori K (1998) Identification of the cis-acting endoplasmic reticulum stress response element responsible for transcriptional induction of mammalian glucose-regulated proteins. Involvement of basic leucine zipper transcription factors. J. Biol. Chem. 273: 33741-33749

77. Yoshida H, Matsui T, Yamamoto A, Okada T and Mori K (2001) XBP1 mRNA is induced by ATF6 and spliced by IRE1 in response to ER stress to produce a highly active transcription factor. Cell 107: 881-891

78. Brown MS, Ye J, Rawson RB and Goldstein JL (2000) Regulated intramembrane proteolysis: a control mechanism conserved from bacteria to humans. Cell 100: 391-398

79. Haze K, Yoshida H, Yanagi H, Yura T and Mori K (1999) Mammalian transcription factor ATF6 is synthesized as a transmembrane protein and activated by proteolysis in response to endoplasmic reticulum stress. Mol. Biol. Cell. 10: 3787-3799

80. Yoshida H, Okada T, Haze K, Yanagi H, Yura T, Negishi M and Mori K (2000) ATF6 activated by proteolysis binds in the presence of NF-Y (CBF) directly to the cis-acting element responsible for the mammalian unfolded protein response. Mol. Cell. Biol. 20: 6755-6767

81. Ye J, Rawson RB, Komuro R, Chen X, Dave UP, Prywes R, Brown MS and Goldstein JL (2000) ER stress induces cleavage of membrane-bound ATF6 by the same proteases that process SREBPs. Mol. Cell 6: 1355-1364

82. Li M, Baumeister P, Roy B, Phan T, Foti D, Luo S and Lee AS (2000) ATF6 as a transcription activator of the endoplasmic reticulum stress element: thapsigargin stress-induced changes and synergistic interactions with NF-Y and YY1. Mol. Cell. Biol. 20: 5096-5106

83. Yoshida H, Okada T, Haze K, Yanagi H, Yura T, Negishi M and Mori K (2001) Endoplasmic reticulum stress-induced formation of transcription factor complex ERSF including NF-Y (CBF) and activating transcription factors 6alpha and 6beta that activates the mammalian unfolded protein response. Mol. Cell. Biol. 21: 1239-1248

84. Shen J, Chen X, Hendershot L and Prywes R (2002) ER stress regulation of ATF6 localization by dissociation of BiP/GRP78 binding and unmasking of Golgi localization signals. Dev. Cell 3: 99-111

85. Lee AS (1992) Mammalian stress response: induction of the glucoseregulated protein family. Curr. Opin. Cell. Biol. 4: 267-273

86. Guo H, Tittle TV, Allen H and Maziarz RT (1998) Brefeldin A-mediated apoptosis requires the activation of caspases and is inhibited by Bcl-2. Exp. Cell Res. 245: 57-68

87. Liu H, Miller E, van de Water B and Stevens JL (1998) Endoplasmic reticulum stress proteins block oxidant-induced $\mathrm{Ca}^{2+}$ increases and cell death. J. Biol. Chem. 273: 12858-12862

88. Lee J, Bruce-Keller AJ, Kruman Y, Chan SL and Mattson MP (1999) 2-DeoxyD-glucose protects hippocampal neurons against excitotoxic and oxidative injury: evidence for the involvement of stress proteins. J. Neurosci. Res. 57: 48-61

89. Yu Z, Luo H, Fu W and Mattson MP (1999) The endoplasmic reticulum stressresponsive protein GRP78 protects neurons against excitotoxicity and 
apoptosis: suppression of oxidative stress and stabilization of calcium homeostasis. Exp. Neurol. 155: 302-314

90. Hendershot LM, Wei JY, Gaut JR, Lawson B, Freiden PJ and Murti KG (1995) In vivo expression of mammalian BiP ATPase mutants causes disruption of the endoplasmic reticulum. Mol. Cell. Biol. 6: 283-296

91. Morris JA, Dorner AJ, Edwards CA, Hendershot LM and Kaufman RJ (1997) Immunoglobulin binding protein (BiP) function is required to protect cells from endoplasmic reticulum stress but is not required for the secretion of selective proteins. J. Biol. Chem. 272: 4327-4334

92. Xiao G, Chung TF, Pyun HY, Fine RE and Johnson RJ (1999) KDEL proteins are found on the surface of NG108-15 cells. Brain Res. Mol. Brain Res. 72 : $121-128$

93. Triantafilou M, Fradelizi D and Triantafilou K (2001) Major histocompatibility class one molecule associates with glucose regulated protein (GRP) 78 on the cell surface. Hum. Immunol. 62: 764-770

94. Delpino A and Castelli M (2002) The $78 \mathrm{kDa}$ glucose-regulated protein (GRP78/BIP) is expressed on the cell membrane, is released into cell culture medium and is also present in human peripheral circulation. Biosci. Rep. 22 407-420

95. Rao RV, Peel A, Logvinova A, del Rio G, Hermel E, Yokota T, Goldsmith PC Ellerby LM, Ellerby HM and Bredesen DE (2002) Coupling endoplasmic reticulum stress to the cell death program: role of the ER chaperone GRP78. FEBS Lett. 514: 122-128

96. Reddy RK, Mao C, Baumeister P, Austin RC, Kaufman RJ and Lee AS (2003) Endoplasmic reticulum chaperone protein GRP78 protects cells from apoptosis induced by topoisomerase inhibitors: role of ATP binding site in suppression of caspase-7 activation. J. Biol. Chem.

97. Wiest DL, Bhandoola A, Punt J, Kreibich G, McKean D and Singer A (1997) Incomplete endoplasmic reticulum (ER) retention in immature thymocytes as revealed by surface expression of 'ER-resident' molecular chaperones. Proc. Natl. Acad. Sci. USA 94: 1884-1889

98. Booth C and Koch GL (1989) Perturbation of cellular calcium induces secretion of luminal ER proteins. Cell 59: 729-737

99. Suzuki T, Yan Q and Lennarz WJ (1998) Complex, two-way traffic of molecules across the membrane of the endoplasmic reticulum. J. Biol. Chem. 273: 10083-10086

100. Henle KJ, Jethmalani SM and Nagle WA (1998) Stress proteins and glycoproteins [Review]. Int. J. Mol. Med. 1: 25-32

101. Reddy RK, Lu J and Lee AS (1999) The endoplasmic reticulum chaperone glycoprotein GRP94 with $\mathrm{Ca}(2+)$-binding and antiapoptotic properties is a novel proteolytic target of calpain during etoposide-induced apoptosis. J. Biol. Chem. 274: 28476-28483

102. Hockenbery D, Nunez G, Milliman C, Schreiber RD and Korsmeyer SJ (1990) $\mathrm{Bcl}-2$ is an inner mitochondrial membrane protein that blocks programmed cell death. Nature 348: 334-336

103. Nunez G, London L, Hockenbery D, Alexander M, McKearn JP and Korsmeyer SJ (1990) Deregulated Bcl-2 gene expression selectively prolongs survival of growth factor-deprived hemopoietic cell lines. J. Immunol. 144: 3602-3610

104. Hockenbery DM, Zutter M, Hickey W, Nahm M and Korsmeyer SJ (1991) Bcl2 protein is topographically restricted in tissues characterized by apoptotic cell death. Proc. Natl. Acad. Sci. USA 88: 6961-6965

105. Hockenbery DM, Oltvai ZN, Yin XM, Milliman CL and Korsmeyer SJ (1993) $\mathrm{Bcl}-2$ functions in an antioxidant pathway to prevent apoptosis. Cell 75: 241251

106. Korsmeyer SJ, McDonnell TJ, Nunez G, Hockenbery D and Young R (1990) Bcl-2: B cell life, death and neoplasia. Curr. Top. Dev. Biol. 166: 203-207

107. Vaux DL, Weissman IL and Kim SK (1992) Prevention of programmed cel death in Caenorhabditis elegans by human bcl-2. Science 258: 1955-1957

108. Vaux DL, Aguila HL and Weissman IL (1992) Bcl-2 prevents death of factordeprived cells but fails to prevent apoptosis in targets of cell mediated killing Int. Immunol. 4: 821-824

109. Reed JC, Miyashita T, Takayama S, Wang HG, Sato T, Krajewski S, AimeSempe C, Bodrug S, Kitada S and Hanada M (1996) BCL-2 family proteins: regulators of cell death involved in the pathogenesis of cancer and resistance to therapy. J. Cell. Biochem. 60: 23-32

110. Lam M, Dubyak G, Chen L, Nunez G, Miesfeld RL and Distelhorst CW (1994) Evidence that BCL-2 represses apoptosis by regulating endoplasmic reticulum-associated $\mathrm{Ca}^{2+}$ fluxes. Proc. Natl. Acad. Sci. USA 91: 6569-6573
111. Thomenius MJ, Wang NS, Reineks EZ, Wang Z and Distelhorst CW (2003) $\mathrm{Bcl}-2$ on the endoplasmic reticulum regulates Bax activity by binding to $\mathrm{BH} 3-$ only proteins. J. Biol. Chem. 278: 6243-6250

112. Vander Heiden MG and Thompson CB (1999) Bcl-2 proteins: regulators of apoptosis or of mitochondrial homeostasis? Nat. Cell. Biol. 1: E209-E216

113. Adams JM and Cory S (2001) Life-or-death decisions by the Bcl-2 protein family. Trends Biochem. Sci. 26: 61-66

114. Rudner J, Jendrossek $V$ and Belka $C$ (2002) New insights in the role of Bcl-2 $\mathrm{Bcl}-2$ and the endoplasmic reticulum. Apoptosis 7: 441-447

115. Nutt LK, Chandra J, Pataer A, Fang B, Roth JA, Swisher SG, O'Neil RG and McConkey DJ (2002) Bax-mediated $\mathrm{Ca}^{2+}$ mobilization promotes cytochrome $C$ release during apoptosis. J. Biol. Chem. 277: 20301-20308

116. Nutt LK, Pataer A, Pahler J, Fang B, Roth J, McConkey DJ and Swisher SG (2002) Bax and Bak promote apoptosis by modulating endoplasmic reticular and mitochondrial $\mathrm{Ca}^{2+}$ stores. J. Biol. Chem. 277: 9219-9225

117. Korsmeyer SJ, Shutter JR, Veis DJ, Merry DE and Oltvai ZN (1993) Bcl-2/Bax: a rheostat that regulates an anti-oxidant pathway and cell death. Semin. Cancer Biol. 4: 327-332

118. Bredesen DE (1996) Keeping neurons alive: the molecular control of apoptosis (part I). Neuroscientist 2: 181-190

119. Bredesen DE (1996) Keeping neurons alive: the molecular control of apoptosis (part II). Neuroscientist 2: 181-190

120. Wang XZ, Lawson B, Brewer JW, Zinszner H, Sanjay A, Mi LJ, Boorstein R, Kreibich G, Hendershot LM and Ron D (1996) Signals from the stressed endoplasmic reticulum induce C/EBP-homologous protein (CHOP/ GADD153). Mol. Cell. Biol. 16: 4273-4280

121. Barone MV, Crozat A, Tabaee A, Philipson L and Ron D (1994) CHOP (GADD153) and its oncogenic variant, TLS-CHOP, have opposing effects on the induction of G1/S arrest. Genes Dev. 8: 453-464

122. Zhan Q, Lord KA, Alamo Jr I, Hollander MC, Carrier F, Ron D, Kohn KW, Hoffman B, Liebermann DA and Fornace Jr AJ (1994) The gadd and MyD genes define a novel set of mammalian genes encoding acidic proteins that synergistically suppress cell growth. Mol. Cell. Biol. 14: 2361-2371

123. Friedman AD (1996) GADD153/CHOP, a DNA damage-inducible protein, reduced CAAT/enhancer binding protein activities and increased apoptosis in 32D c13 myeloid cells. Cancer Res. 56: 3250-3256

124. Zinszner $H$, Kuroda M, Wang X, Batchvarova N, Lightfoot RT, Remotti $H$, Stevens JL and Ron D (1998) CHOP is implicated in programmed cell death in response to impaired function of the endoplasmic reticulum. Genes Dev. 12: 982-995

125. McCullough KD, Martindale JL, Klotz LO, Aw TY and Holbrook NJ (2001) Gadd153 sensitizes cells to endoplasmic reticulum stress by downregulating $\mathrm{Bcl} 2$ and perturbing the cellular redox state. Mol. Cell. Biol. 21: 1249-1259

126. Rao R, Poksay K, Castro-Obregon S, Schiilling B, Row RH, dcl Rio G, Gibson BW, Ellerby HM and Bredesen DE (2004) Molecular components of a cell death pathway activated by endoplasmic roticulum stross. J. Biol. Chem. 279: 177-187

127. Vale RD (2000) AAA proteins. Lords of the ring. J. Cell Biol. 150: F13-9

128. Lord JM, Ceriotti A and Roberts LM (2002) ER dislocation: Cdc48p/p97 gets into the AAAct. Curr. Biol. 12: R182-4

129. Dalal S and Hanson PI (2001) Membrane traffic: what drives the AAA motor? Cell 104: 5-8

130. Kobayashi T, Tanaka K, Inoue K and Kakizuka A (2002) Functional ATPase activity of p97/valosin-containing protein (VCP) is required for the quality control of endoplasmic reticulum in neuronally differentiated mammalian PC12 cells. J. Biol. Chem. 277: 47358-47365

131. Hirabayashi M, Inoue $K$, Tanaka $K$, Nakadate $K$, Onsawa $Y$, Kamei $Y$, Popiel AH, Sinohara A, Iwamatsu A, Kimura Y, Uchiyama Y, Hori S and Kakizuka A (2001) VCP/p97 in abnormal protein aggregates, cytoplasmic vacuoles, and cell death, phenotypes relevant to neurodegeneration. Cell Death Differ. 8: 977-984

132. Vito $P$, Lacana $E$ and D'Adamio $L$ (1996) Interfering with apoptosis: $\mathrm{Ca}(2+)$ binding protein ALG-2 and Alzheimer's disease gene ALG-3. Science 271: $521-525$

133. Vito P, Pellegrini L, Guiet C and D'Adamio L (1999) Cloning of AIP1, a novel protein that associates with the apoptosis-linked gene ALG-2 in a $\mathrm{Ca}^{2+}$ dependent reaction. J. Biol. Chem. 274: 1533-1540 
134. Lacana E, Ganjei JK, Vito P and D'Adamio L (1997) Dissociation of apoptosis and activation of IL-1beta-converting enzyme/Ced-3 proteases by ALG-2 and the truncated Alzheimer's gene ALG-3. J. Immunol. 158: 5129-5135

135. Jung YS, Kim KS, Kim KD, Lim JS, Kim JW and Kim E (2001) Apoptosislinked gene 2 binds to the death domain of Fas and dissociates from Fas during Fas-mediated apoptosis in Jurkat cells. Biochem. Biophys. Res. Commun. 288: 420-426

136. Kilic M, Schafer R, Hoppe J and Kagerhuber U (2002) Formation of noncanonical high molecular weight caspase-3 and -6 complexes and activation of caspase-12 during serum starvation induced apoptosis in AKR2B mouse fibroblasts. Cell Death Differ. 9: 125-137

137. Hoppe J, Kilic M, Hoppe V, Sachinidis A and Kagerhuber U (2002) Formation of caspase-3 complexes and fragmentation of caspase-12 during anisomycininduced apoptosis in AKR-2B cells without aggregation of Apaf-1. Eur. J. Cell Biol. 81: 567-576

138. Rao RV, Castro-Obregon S, Frankowski H, Schuler M, Stoka V, Del Rio G, Bredesen DE and Ellerby HM (2002) Coupling endoplasmic reticulum stress to the cell death program. An Apaf-1-independent intrinsic pathway. J. Biol. Chem. 277: 21836-21842

139. Yoneda T, Imaizumi K, Oono K, Yui D, Gomi F, Katayama T and Tohyama M (2001) Activation of caspase-12, an endoplastic reticulum (ER) resident caspase, through tumor necrosis factor receptor-associated factor 2dependent mechanism in response to the ER stress. J. Biol. Chem. 276: 13935-13940

140. Morishima N, Nakanishi K, Takenouchi H, Shibata T and Yasuhiko Y (2002) An endoplasmic reticulum stress-specific caspase cascade in apoptosis.
Cytochrome $c$-independent activation of caspase-9 by caspase-12. J. Biol. Chem. 277: 34287-34294

141. Oubrahim H, Chock PB and Stadtman ER (2002) Manganese(II) induces apoptotic cell death in NIH3T3 cells via a caspase-12-dependent pathway. J. Biol. Chem. 277: 20135-20138

142. Bitko V and Barik S (2001) An endoplasmic reticulum-specific stress-activated caspase (caspase-12) is implicated in the apoptosis of A549 epithelial cells by respiratory syncytial virus. J. Cell. Biochem. 80: 441-454

143. Fischer $H$, Koenig U, Eckhart $L$ and Tschachler $E$ (2002) Human caspase 12 has acquired deleterious mutations. Biochem. Biophys. Res. Commun. 293: 722-726

144. Breckenridge DG, Stojanovic M, Marcellus RC and Shore GC (2003) Caspase cleavage product of BAP31 induces mitochondrial fission through endoplasmic reticulum calcium signals, enhancing cytochrome $c$ release to the cytosol. J. Cell Biol. 160: 1115-1127

145. Granville DJ, Carthy CM, Jiang $H$, Shore GC, McManus BM and Hunt DW (1998) Rapid cytochrome $c$ release, activation of caspases 3, 6, 7 and 8 followed by Bap31 cleavage in HeLa cells treated with photodynamic therapy. FEBS Lett. 437: 5-10

146. Maatta J, Hallikas $O$, Welti S, Hilden $P$, Schroder $J$ and Kuismanen $E$ (2000) Limited caspase cleavage of human BAP31. FEBS Lett. 484: 202-206

147. Ng FW and Shore GC (1998) Bcl-XL cooperatively associates with the Bap31 complex in the endoplasmic reticulum, dependent on procaspase-8 and Ced4 adaptor. J. Biol. Chem. 273: 3140-3143 